\title{
Trust formation process in Islamic banking in Malaysia
}

\author{
Marlehan bin Mohamed ${ }^{*}$, Mohd Nizam Bin A. Badaruddin and Chee-Keong Choong
}

Department of Entrepreneurship, Faculty Business and Finance, Universiti Tunku Abdul Rahman, Perak Campus, Jalan Universiti, Bandar Barat, 31900 Kampar, Perak Darul Ridzuan, Malaysia.

Accepted 2 June, 2010

\begin{abstract}
An increasing number of citizens are doing transaction with Islamic banks and the numbers are likely to increase rapidly in the future. Research shows that trust is the key factor before undertaking transaction. However, much of our understanding about the trust is still in the embryonic stage especially in the Islamic banking industry. Hence, this study focuses on trust in the context of engaging in Islamic banking transactions and to address its evolutionary nature and associated factors. This article explores the trust antecedent, trust behavior and trust consequence in selecting Islamic banking. The uniqueness of this paper is that it develops a model for trust process/construct in Islamic banking. This is deemed essential in order to market the Islamic banking products and services that can truly enable and support lasting relationships in commercial settings.
\end{abstract}

Key words: Trust, antecedents, Islamic bank, finance, model.

\section{INTRODUCTION}

Islamic finance is seen as an alternative financing option by the international financial community. It is seen as more stable and more resilient to the economic downturn. It is believed that Islamic finance serves as a vehicle for recovering from the international financial crisis. Islamic finance has begun to gain widespread reputation since 1970s. The market keeps expanding internationally with assets ranging form 800 billion to 1 trillion and still expanding between 10 to $15 \%$ annually (Shayerah, 2009). Timewell (2009) has argued that Islamic banking industry may be able to strengthen its position in the international market as investors and companies seek alternative sources of financing.

Trust has been the study of organizational behavior over many years. It takes a few dimensions such as integrity, competence, consistency, loyalty and openness. It may be defined as positive expectation that another will not - through words, actions, or decisions - act opportunistically (Robbins, 2005). In response to this, Islamic banking which is a major component of Islamic Finance has a good competitive advantage that will enhance higher performance. Hence, this paper attempts to look into the trust formation process in the Islamic banking industry.

\footnotetext{
${ }^{*}$ Corresponding author. E-mail: marlehanm@utar.edu.my.
}

\section{Current development in the Islamic Banking}

The significance of Islamic finance in Malaysia is no longer deniable. On the whole, it keeps growing and as at June 2007, assets of Islamic banking system grew $8.5 \%$ year on year to RM143.7 billion (2006: RM133 billion). It accounted for $12.1 \%$ of total banking system assets. Such growth was driven by the expansion in Islamic finance activities of $3.8 \%$ year on year from RM78.7 billion in 2006 to RM81.5 billion in 2007. That contributed to $13.3 \%$ of total banking system financing (Baljeet, 2008).

On a global level, the growth is also pretty sound. Moody's Investors Service stated that the estimated Islamic financial market size was USD700 billion, with an annual growth rate of $15 \%$ over the past three years (Moody's, 2008). Thus, the study about trust is no doubt significant. It is expected that the study would be of value added to business decision making and marketing of the financial products among the emerging Islamic banks which attempt to provide viable alternatives to existing conventional banking.

\section{Research problem}

Trust in Islamic bank sparks the interest of many people to be willing to transact with it. We recognize the fact that 
Islam and Muslims are currently experiencing period of multiple challenges. Yet, despite these challenging moments, data about the growth in Islamic Finance speaks differently. How could trust be built in this kind of environment when prejudice is still apparent especially after $9 / 11$ tragedy? We therefore take this initiative to look at the mechanism of trust in Islamic banking. Although studies about trust in online transactions have been quite many especially during dot com bust in the early 2000s, the trust aspect has not been discovered in Islamic finance and Islamic banking yet. This study therefore, aims to fill in this knowledge gap by focusing on the trust formation process in Islamic banking. The paper uses literature review of past research and documents on the trust formation model.

\section{Problem statement}

The trust factors in Malaysian Islamic banking that are resistant to current political setbacks surrounding Islam and Muslim globally.

\section{Research objectives}

\section{General objective}

The objective of the study is to understand mechanics behind trust formation process in Islamic banking whilst investigating factors that are resistant to current scenario.

\section{Specific objectives}

1. To identify antecedents to trust in Islamic banking.

2. To establish relationship between Malaysia's collectivism culture and its sensitivity towards trust.

3. To establish relationship between Fiqh Muamalat concepts and its sensitivity towards trust.

4. To establish relationship between perceived ability, integrity, predictability and benevolence of Islamic bankers and its sensitivity towards trust.

\section{Research questions}

To answer the following research questions:

1) What are the antecedents to trust in Islamic banking?

2) How Malaysia's collectivism affect trust sensitivity?

3) How Fiqh Muamalat concepts affect trust sensitivity?

4) How perceived ability, integrity, predictability and benevolence affect trust sensitivity?

\section{Research significance}

The outcome of research may benefit many parties directly or indirectly in the following ways:

1. Islamic Banker: Trust formation understanding shall serve as a guidance or blueprint at the strategic level of business decision. On a more specific level such as marketing function, decision makers at the Islamic Bank are able to use the model in order to prioritize its marketing strategy.

2. Shareholders of Islamic Banker: Shareholder of an Islamic bank clearly has as good direct benefit as the bank itself. A profitable Islamic banking entity would surely promise them decent return, thus increasing value of investment.

3. Government: Government, being a socially oriented body has been working to promote Islamic finance and brings it to a greater height. Trust from the locals is important to generate domestic growth of economy, thus enhancing gross domestic product. Thereafter, foreign direct investment is expected to flourish if trust is solid and strong. This is pretty visible of late with the emergence of Kuwait Finance House, Al-ljarah Bank and Standard Chartered Saadiq Bank, to name a few making their presence in the Islamic banking scene.

4. Other beneficiaries: The benefits would clearly expand to some other bodies, organizations or professions who have economic or social benefit out of the growth in Islamic banking generally. They are central banker, financial analyst, entrepreneur, academician, critic and public at large. Of course, the list is never exhaustive as we highlight only those that are obvious.

\section{Definition of trust}

Trust is very complex construct and it has various dimensions (Gefen, 2000; McKnight et al., 1995). Trust is very difficult to define and measure and lack of research found in financial institution. The definition of trust has varied from field to field but the definitions that is widely accepted is by Mayer et al., (1996) stating that trust is "the willingness of a party to be vulnerable to the actions of another party based on the expectation that the other will perform a particular action important to the trust or irrespective of the agility to monitor or control that other party". For the purpose of this study, the definition of trust suggested by Mayer will be employed.

\section{Trust antecedents identified in the literature}

\section{Disposition to trust}

Islam emphasized the importance of trust via the Holy Qur'an.

"God doth command you to render back your Trusts to those to whom they are due; And when ye judge between man and man, that ye judge with justice: Verily how excellent is the teaching which He giveth you! For God is He who heareth and seeth all things (Qur'an 4: 58). If ye are on a journey, and cannot find a scribe, a pledge with possession (may serve the purpose). And if one of you 
deposits a thing on trust with another, let the trustee (faithfully) discharge his trust, and let him fear his Lord. Conceal not evidence; for whoever conceals it,- His heart is tainted with sin. And God knoweth all that ye do (Qur'an 2: 283)".

Disposition to trust is a general orientation to trust others. It arises from personality and cultural factors. It is believed that different personality and culture possess different level of willingness to trust others. In addition to that, disposition to trust is not directed towards specific trustee but on the general environment in which a trustee operates in. (Panagiota et al., 2002).

We posit that disposition to trust here applies to Islamic finance landscape on the whole. Personality wise, disposition to trust encompasses a client's general attitude towards Islamic finance, which may include his perception and thought. Disposition to trust is also propelled from cultural factor.

One aspect worth considering is collectivism versus individualism because these cultural values have gained more attention than other cultural dimensions (Mc Shane et al., 2005).

Hofstede, G. (2001) has identified four dimensions of culture in all the nations that he studied.

Recent study by Gelfand et al., (2006), shows that nine cultural values that they called cultural constructs. One of these cultural values will be examined as it is relevant to the trust formation which is collectivism. According to Rachagan and Satkunasingam (2009), the level of collectivism in Malaysia plays a large role in most companies. Therefore it is very clear that Malaysia is categorized in collectivism society.

Hence, the trust formation in collectivism society is inclined towards stronger belief, behavior, intention and environment. The individualism and collectivism measure the degree of integration among members of a society. This has implication on the structure of the family, religion, politics and education and society at large (Hofstede, 2001).

Culture affects perceived ability, integrity, predictability and benevolence towards a trustee to a varying degree. Collectivism shows higher sensitivity to contextual signs such as predictability and benevolence in order to trust a party. On the other hand, individualism is more sensitive to dispositional signs such as ability and integrity.

Is building trust in an organization as good as building trust in a natural person? It may not be equivalent; however it arises from interactions with the organizations' representatives (Branzei et al., 2007). The change in individuals would, to a certain degree, affect organizational trust (Branzei et al., 2007).

\section{Institution based trust}

Institution based trust refers to structural trust. In this context, it refers to specific propriety of Islamic banking. Islamic banking is a banking activity which is consistent with the Islamic law (Sharia). It is carried out in accordance with the rules of Sharia known as figh muamalat (Islamic rules of transactions). The rules and norms of figh muamalat emanate from two primary sources of Sharia namely Quran and Sunnah and other secondary and authoritative sources of Islamic law.

Thereafter, various Sharia concepts emanate from the afore statement. These concepts are Wadiah (safekeeping), Mudharabah (profit sharing), Musyarakah (joint venture), Murabahah (cost plus), Bai'Bithaman Ajil (deferred payment sale), Wakalah (agency), Qard (interest free loan), ljarah Thumma Bai' (hire purchase) and Hibah (gift).

There is no doubt that these concepts create trust among the potential client. However, the degree of understanding about Islamic banking among different people is varied. As such, trust in this respect is expected to correspond to the degree of knowledge one has about these concepts.

\section{Initial trusting belief}

Trusting beliefs are defined as the extent to which one believes that the other person involved in a relational exchange is trustworthy.

Trusting belief is influenced by trustee's four major attributes. They are ability, integrity, predictability and benevolence (Mc Knight et al., 1996).

Ability: Competency, expertise and capability represent major indications of a trustee's ability. It refers to the quality possessed by a trustee to deliver specific set of tasks (Mayer and Davis, 1999).

There are two distinct aspects.

They are professional designation and relational/task focus. The aspect of ability in Islam goes beyond one's wealth and personal ranking in society. In fact, the knowledge gifted by Allah is a more dominant attribute.

Their Prophet said to them: "God hath appointed Talut as King over you." They said: "How can he exercise authority over us when we are better fitted than he to exercise authority, and he is not even gifted, with wealth in abundance?" He said: "God hath Chosen him above you, and hath gifted him abundantly with knowledge and bodily prowess: God Granteth His authority to whom He pleaseth. Allah is All-Embracing, and He knoweth all things (Qur'an 2: 247).

Professional designation is associated with specific profession, training and institution that provide a guarantee for a high level of competency, expertise and a desired level of capability (Mc Knight et al., 1998). Professional designation moderates the feeling of anxiety, 
ambiguity and overwhelming. Thus, it helps to mitigate risk of unreliability (Sheppard and Sherman, 1998). Therefore, unfamiliarity with a trustee can be reached via professional designation.

In an Islamic banker context, professional designation applies to professionalism of its high level management which is later translated into the actions of its personnel in order to carry out the job. The business of Islamic banking is highly regulated. It is governed by Islamic banking Act, 1983, an Act to provide for the licensing and regulation of Islamic banking business. Another aspect of ability is task focus.

It refers to trustee's preferences and intentions to realize the strategies and goals set out to achieve benefit for all. When such commitment is displayed, the trustor is reassured that the trustee is capable of meeting technical expectations (Doney at al., 1998). According to Gefland et al., (2006), maximizing the economic value of exchange is the prime concern of task focused trustee. For an Islamic banker, task focus ability is associated with the ability to run a profitable business thus maximizing the client's financial interest. For collectivist culture, relational focus is no less important because it strengthens their connection with the trustor (Cross, Morris, and Gore, 2002).

Integrity: Integrity arises from compliance to a set of principals that the trustor finds acceptable, fair and consistent (Mayer et al., 1995). Integrity has two values; consistency - that the trustee's action is consistent with his verbal and written promises. In Islam, a good example to describe integrity is an incidence where Umar AlKhattab, the second Caliph sought permission from public to use honey from Bayt al-mal. Despite holding the highest office in government administration, he did not just preach but demonstrated an act that supported his preaching. In our discussion, we can term it as 'walk the talk' and congruence - that the trustee's intentions are aligned with the trustor's expectations (Sitkin and Roth, 1993). It is difficult to measure intention. However, Islam gives significant importance to intention despite its difficulty.

"Umar b. al-Khattab narrated that the Prophet (S) said: Deeds are [a result] only of the intentions [of the actor], and an individual is [rewarded] only according to that which he intends. Therefore, whosoever has emigrated for the sake of Allah and His messenger, then his emigration was for Allah and His messenger. Whosoever emigrated for the sake of worldly gain, or a woman [whom he desires] to marry, then his emigration is for the sake of that which [moved him] to emigrate (Bukhari and Muslim)."

As such, consistency is a more applicable value when it comes to trust in Islamic banking. Voluntary promise is a prerequisite for consistent behavior. It is symbolized via contractual agreements. Contractual agreement binds both trustor and trustee as for the risk and rewards of the outcome. There are mutually accepted and typically durable and resistance to change (Rosseau, 1995). Making and keeping voluntarily promises is a sign of integrity (Malhotra and Murnighan, 2002).

An Islamic banker makes and keeps voluntarily promises by sealing transparent agreements while leaving no doubts feeling to its clients. This is done to any financial transaction/agreement such as Wadiah (custody or safekeeping), Mudharabah (a profit sharing arrangement between two parties, that is, an investor and the entrepreneur), Musyarakah (a partnership or a joint business venture to make profit. Profits made will be shared by the partners based on an agreed ratio which may not be in the same proportion as the amount of investment made by the partners), Murabahah (the sale of goods at a price which includes a profit margin agreed by both parties., Bai' Bithaman Ajil (the sale of goods where the buyer pays the seller after the sale together with an agreed profit margin, either in one lump sum or by instalment)., Wakalh (a contract whereby a person (principal) asks another party to act on his behalf (as his agent) for a specific task), Qard ljarah Thumma Bai' (financing consumer goods especially motor vehicles) and Hibah (a payment made willingly in return for a benefit received).

Lastly, when the action is consistent with what is promised in the agreement, trusting belief is going to be strong and solid.

Predictability: As the name suggests, predictability is associated with trustee's future behavior. It is predictable when such behavior falls within a desired range (Doney et al., 1998). The feeling of uncertainty could be substantially reduced when what is 'normally' expected of a trustee acting in the best interest of all is clear (Mayer and Davis, 1999).

The development of trust via predictability is influenced by two signs; dissimilarity and thwarted connection

(Branzei, 2007). Dissimilarity sign is apparent when a trustee belongs to a different social system (McKnight et al., 1998). On the other hand, thwarted connection occurs when a trustee attempts to handle minor initial disagreements with a trustor (Cross and Madson, 1997).

The focus is on minor threats which may not reflect poorly on a trustor (Jetten et al., 2005). For example, a confrontational approach, as opposed to relational approach, to a certain degree, may impair trust formation. Dissimilarity sign is more prevalent in our Islamic banking discussion.

This is due to less personal contact taking place in any banking transaction.

For Muslims, an Islamic banker is a bank that attempts to bring back the real teaching of Islam in respect of Figh Muamalat or Islamic rules of transactions.

As such, it is viewed as predictable since the entity (as 
represented by its top personnel and policy makers) has common belief with the client with respect to Islam as a way of life.

Predictable shall apply to aspects of upholding, in entirety, the principle of Islamic Sharia and in accordance with the rules of Sharia known as Fiqh Muamalat.

For non Muslim, Islamic bank is viewed as predictable because they share the common belief on ethics, moral and value.

Therefore, it is no wonder that Islamic banking is well accepted by Non Muslims in Malaysia too.

Benevolence: The concept of benevolence is very clear in the Qur'an. The Holy Qur'an highlights the aspect of trustworthy relationship and helping others in good deeds which symbolizes signs of cooperation and loyalty respectively.

Recalling the earlier ayah (Qur'an 2: 283) in the disposition to trust discussion, a good lesson to be derived is a partial interpretation of the ayah as follow:

"Ibn Abi Hatim recorded, with a sound chain of narration, that Abu Sa id Al-Khudri said, "This Ayah abrogated what came before it (i.e. that which required recording the transaction and having witnesses present)."

Ash-Sha 'bi said, "If you trust each other, then there is no harm if you do not write the loan or have witnesses present."

Another ayah in the Qur'an highlights loyalty but only in good deeds and not the evil ones.

"O ye who believe! Violate not the sanctity of the symbols of God, nor of the Sacred Month, nor of the animals brought for sacrifice, nor the garlands that mark out such animals, nor the people resorting to the sacred house, seeking of the bounty and good pleasure of their Lord. But when ye are clear of the Sacred Precincts and of pilgrim garb, ye may hunt and let not the hatred of some people in (once) shutting you out of the Sacred Mosque lead you to transgression (and hostility on your part). Help ye one another in righteousness and piety, but help ye not one another in sin and rancour: fear God: for God is strict in punishment (Qur'an 5: 2)."

Trust by mean of benevolence occurs when there are signs of cooperation, reciprocity and loyalty from the trustee; for example, by delivering, caring and understanding the needs of trustee beyond what is required or rewarded obligations (Doney et al., 1998; Mayer and Davis, 1999; Mayer et al., 1995).

Transacting in any economic exhange may have its challenges.

Trustor has deep interdependence on the trustee whereas the trustee may not act in the best interest of trustor if element of care is absent.

As such, it is important for both trustor and trustee to anticipate each other's needs and to be willing to accommodate them so that benevolence-based trust can be fostered (Shepperd and Sherman, 1998).

Relational reputation is a good testimony to foster benevolence-based trust.

It is based on the third party's experience with the trustee. Islamic banker displays its benevolence-based trust via testimonies from the existing clients.

For example, Islamic banker has proven that it is committed to maximizing the value of transaction, functioning as a Zakat collection centre and being responsible in the partnership agreement.

Caring in this context goes beyond financial interest.

It is also applied to caring about the client's sensitivity with regard to upholding the function and operation modes purely based on Islamic principle of Sharia.

The model given in Figure 1 explains series of experiences undergone by a prospective client, thereafter becoming as a client as he transacts with Islamic banker. Disposition to trust, institution based trust and initial trusting belief are the antecedents.

Each one would either singly, or in some combination with other antecedents affect the decision to transact with Islamic banker.

Consequently, a client would maintain an existing transaction, undertake new transaction or terminate a transaction depending on the level of satisfaction.

\section{Limitation}

The following limitations have been observed in respect of this paper:

1) The trust level of an individual client or an organization towards Islamic banker is not distinguished;

2) The paper is silent about time dimension. It is acknowledged that time shall have certain influence on the depth of trust antecedents; and

3) The emotional aspect of trust is not addressed. Emotions may produce temporary 'irrationality' while evaluating initial trusting belief that is, ability, integrity, predictability and benevolence.

\section{Conclusions}

The study represents a major effort at identifying elements of trust in the Islamic banking. It introduces disposition to trust, institution based trust and initial trusting belief as antecedents to trust. It is expected that there is a strong correlation between trust antecedents and the trusting behavior, being a client's decision to undertake transaction with Islamic banker. Islamic banker provides better grounds to be trusted because s/he has inbuilt characteristic to be trusted provided she/he follows Islamic way of life. Islamic banker is answerable for his action in this world and the world to come, a strong binding for him to be trustworthy. A few ayahs below provide ultimate sense about how responsible is Islamic 


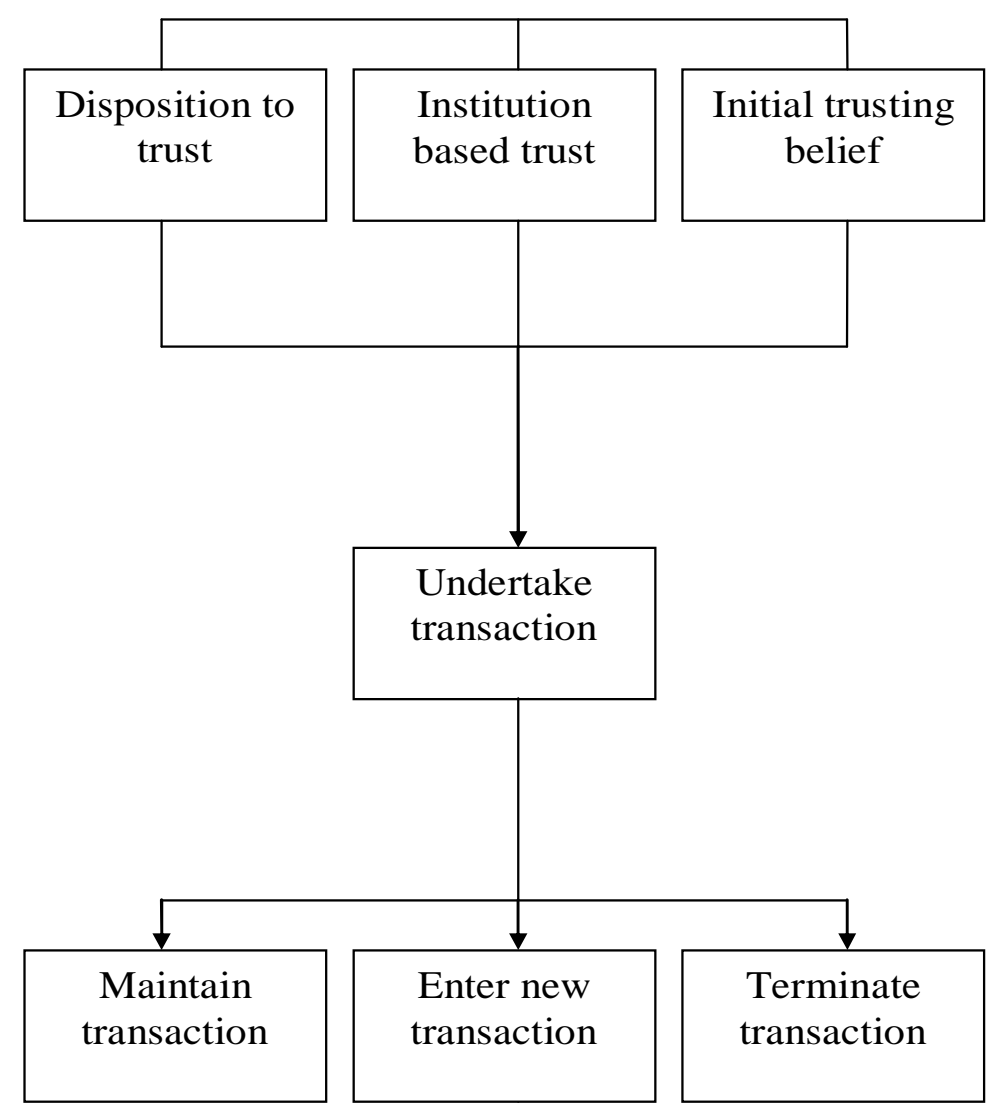

Figure 1. Trust formation model.

banker supposed to be:

"Then shall anyone who has done an atom's weight of good, see it!. And anyone who has done an atom's weight of evil, shall see it (Qur'an 99: 7-8).

Nor can a bearer of burdens bear another's burdens if one heavily laden should call another to (bear) his load. Not the least portion of it can be carried (by the other). Even though he be nearly related. Thou canst but admonish such as fear their Lord unseen and establish regular Prayer. And whoever purifies himself does so for the benefit of his own soul; and the destination (of all) is to God (Qur'an 35: 18)."

We expect this is especially so for institution based trust because it represents the uniqueness of Islamic banking. Thereafter, satisfaction gained from the initial transaction would have a strong influence on a client's later decision to either maintain, undertake new or to terminate transaction.

\section{REFERENCES}

Baljeet K.G (2008) "Malaysian Islamic Finance Landscape; Islamic Finance news Guide, pp. 27-30. www.islamicfinancenews.com.
Branzei O, Vertinsky I, Ronald DC (2007) Culture-contingent sign of trust in emergent relationship, Organ. Behav. Hum. Decis. Process., 104: 61-82.

Cross SE, Morris ML, Gore JS (2002) Thinking about oneself and others: The relational-interdependent self-construal and social recognition. J. Personality Social Psychol., 3: 399-418.

Cross SE, Madson L (1997) Models of the self: Self-construal's and gender. Psychol. Bull., 122: 5-37.

Doney PM, Cannon JP, Mullen MR (1998) Understanding the influence of national culture on the development of trust, Acad. Manage. Rev., 23: $601-620$.

Gefen D (2000) E-commerce: the role of familiarity and trust. Omega Int. J. Manage. Sci., 28: 725-737.

Gelfand MJ, Major VS, Raver JL, Nishii L., O'Brien K (2006) Negotiating rationally: The dynamics of the relational self in negotiations. Acad. Manage. Rev., 31(2): 427-451.

Hofstede, G. (2001) Culture's consequences: $2^{\text {nd }}$ ed. Beverly Hills: Sage

Jetten J, Summerville N, Hornsey MJ, Mewse AJ (2005) When differences matter: Intergroup distinctiveness and the evaluation of impostors. Eur. J. Social Psychol., 35: 609-620.

Malhotra D, Murnighan JK (2002) The effects of contracts on interpersonal trust, Administrative Science Quart., 47: 534-559.

Mayer RC, Davis JH (1999). The effect of the performance appraisal system on trust in management: A field Quasi experiment, J. Appl. Psychol., 84(1): 123-136.

Mayer RC, Davis JH, Schoorman FD (1995) An integrative model of organizational trust, Acad. Manage. Rev., 20(3): 709-734.

McKnight DH, Cummings LL, Chervany NL (1998) Initial trust formation in new organizational relationships, Acad. Manage. Rev., 23(3): 473490.

McKnight DH, Chervany NL (1996) The meaning of trust. MISRC 
Working Paper. Electronic publication. URL:http//misc,umn.edu.wpaper/WprkingPapers/9604.pdf.

Panagiota P, Panagiotis K, Drakoulis M (2002) Trust Formation and Relationship Building in Electronic Services capes. ECIS June 6-8, Gdansk, Poland.

Rachagan S, Satkunasingam E (2009) Improving corporate governance of SMEs in emerging economies: A Malaysian Experience, J. Enterp. Inform. Manage., 22(4): 468-484.

Robbin S (2005) Organization Behavior, ( $3^{\text {rd }}$ ed.). McGrew-Hill Irwin.

Shayerah I (2009) "Islamic Finance: Overview and Policy Concerns" Analyst in International Trade and Finance, Congressional Research Service.
Sheppard BH, Sherman DM (1998) The grammars of trust: A model and general implication, Acad. Manage. Rev., 23(3): 422-437.

Sitkin SB, Roth NL (1993) Explaining the limited effectiveness of legalistic "remedies" for trust/distrust, Organ. Sci., 4(3): 367-392.

The Hadith of the Prophet (PBUH).

The Holy Qur'an

Timewell S (2009) Top 50 Islamic Financial Institute http://islamicfinanceandbanking.blogspot.com/2009_03_01_archive.h tml. 